\title{
Similarity Analysis of Robusta Coffee Plant (Coffea robusta L.) at Three Altitudes in Merangin District, Jambi Province
}

\author{
Acep Sopandi*, Zulfadly Sayrif, Reni Mayerni
}

Faculty of Agriculture, Andalas University, Padang

*Email: acep.umb@gmail.com

\begin{abstract}
Coffee is one of the plantation crops that has been developed and has become a commodity that is taken into account in strengthening the country's foreign exchange. The purpose of this study is to identify the similarity of robusta coffee plants at three heights in Merangin Regency, Jambi Province. The study began in October-November 2019 in Merangin District, Jambi Province using the survey method. The value of the coefficient of similarity is at $33 \%$ which indicates that the degree of similarity is small. Heavy wet per 100 pieces of ripe, long bean coffee, as well as weight per 100 grains of coffee robusta scale on levels of water $12 \%$, shows increasingly higher altitude of the place is getting better.
\end{abstract}

Keywords - Phenotype, commodity, diversity, similarity, morphology.

\section{INTRODUCTION}

Coffee plant ( Coffea sp.) Is one of the plantation crops that was developed since the Dutch colonialism. This plant has become a commodity that is taken into account in strengthening the country's foreign exchange. This can be seen from the data of production, exports, and the area of Indonesian coffee. In 2016 - 2017 Indonesian coffee production and export ranked 4th in the world under Brazil, Vietnam, and Colombia (ICO, 2017 ). The volume and value of Indonesia's coffee exports in the last 5 years (2013-2017) experienced fluctuations, where the highest achievement was in 2013 which was 534,023 tons with an export value of US $\$ 1,174,029,000$, while the lowest export volume occurred in 2014 which was 384,618 tons with export value of US \$1,039,341 (Directorate General of Plantation Ministry of Agriculture, 2018).

The development of the area of coffee plantations in Indonesia in the last 5 years (2014-2018) averaged $1,238,417$ ha with an average production of 686,097 tons in the year -1 -. The amount is dominated by smallholder plantations at $96.18 \%, 1.84 \%$ owned by state plantations and $3.77 \%$ privately owned (Dirjend Perkebunan, 2018). As for production, it reaches $94.99 \%$ of smallholder plantations, $2.51 \%$ of State plantations, and $2.50 \%$ of private plantations (Directorate General of Plantations, Ministry of Agriculture, 2018).

The growth of world coffee consumption is faster than the growth of world coffee production in the period 2012-2017. Growth in world coffee production only reached 1.18 percent while world consumption growth doubled from its production. (GAEKI, 2014).

Coffee plants that develop in Indonesia consist of Arabica and Robusta coffee. Both of these coffees have a high level of demand compared to other types of coffee. However, both copies have several problems, especially in terms of productivity. ( Directorate General of Plantations, Ministry of Agriculture, 2018).

In Jambi Province, the highest number of coffee areas and production was found in Merangin District, which was $41.40 \%$ and $50.13 \%$ of the total area and production of coffee plants in Jambi Province, while the second-largest was Kerinci District with a total of $28.88 \%$ and $29.85 \%$, the rest was spread over 8 (eight) Regencies / Cities namely West Tanjung Jabung, East Tanjung Jabung, Tebo, Bungo, Batang Hari, Muaro Jambi, Sungai Penuh and Jambi City-. Of the two types of coffee developed in Jambi Province namely Robusta and Arabica, Robusta coffee dominates the area of coffee plants in Jambi Province at $94.24 \%$ of the total 26,660 ha (BPS Jambi, 2018).

In addition to productivity issues, other problems, especially plant pests (OPT), seed quality and coffee flavor are challenges for Indonesia. Arabica coffee is susceptible to leaf rust caused by the pathogen Hemileia vastatrix, especially at an altitude of 600 - $700 \mathrm{~m}$ above sea level. The vulnerability of Arabica coffee to leaf rust disease is a limiting factor for production because this coffee is only better planted at a height of more or equal to $1000 \mathrm{~m}$ above sea level. Robusta coffee has properties that are more 
resistant to the pathogen Hemileia vastatrix, so that this coffee can be planted at an altitude of fewer than $1000 \mathrm{~m}$ above sea level and optimum at an altitude of $600-700 \mathrm{~m}$ above sea level. However, its flavor is not as good as Arabica coffee (Indrawanto, et al ., 2010). Also Besides, coffee borer (PBKo) is an important problem in coffee cultivation.

These problems can be overcome by searching for coffee germplasm that has the expected characteristics through a breeding program. Germplasm character evaluation is one of the important activities in the breeding program that identifies the character and kinship of germplasm with a different visual appearance so that it can facilitate genetic management. Morphological characterization also has a major role in efforts to conserve germplasm, so that the continuity of information on the diversity of coffee plants can be well established (Soeroso, 2012). These efforts can assist breeders in making wise selections to get the expected plants. The purpose of this study is to find out the morphological diversity and similarity of robusta coffee plants at three heights in Merangin Regency, Jambi Province.

\section{RESEARCH METHODS}

The study began in October-November 2019 in Merangin District, Jambi Province using the survey method. The materials used in this study include coffee plants and their parts such as stems, leaves, flowers, fruit, and seeds . While the tools used are the ruler, meter, digital calipers, plastic bags, envelopes, digital cameras, GPS ( Global Position System ), Lux meters, digital altimeters , soil testers, paper bells, ladders, knives, machetes, Color Chart for Plant tissue and stationeries (pens, pencils, sipidol, and paper). Similarity analysis is performed using a statistical calculation program, the NTSYS Ver.2.02 program.

\section{DISCUSSION RESULT}

Analysis of similarity aims to determine the distance of flower similarity between the genotype of a plant by using the properties of morphological. The nature of morphologic use to the introduction and display the similarity in kind. Of the 54 accessions of crops of coffee robusta in three heights in the District Merangin that observed , analysis similarity with using program Numerical Taxonomy and Multivariate Analysis System version 2.10e. ( NTSys ) to produce robusta coffee grouping ( Figure 1). The analysis is used to determine distance relationship resemblance between the genotype of a plant using properties its morphology . The morphology can be used for recognition that illustrates similarities in types. The type that has a resemblance to close has many similarities between the type of the other ( Balkaya et al ., 2009).

In dendogram 54 accessions of crops of coffee robusta in three heights in the Merangin District province of Jambi on the character of qualitative were compared to show the coefficient of similarity with the value of $33-100 \%$ ( Figure 1). The similarity coefficient value is an indication of the level of similarity of a plant. The more small value of the coefficient of similarity indicates getting smaller also the level of similarity between genotype was compared. It is meant also the level of diversity among genotype was compared to getting high if the large securities similarity coefficient values indicate the greater the degree of similarity between plants being compared and the smaller the level of diversity. According to Cahyarini (2004), the value of the coefficient of similarity $<60 \%$ means having similarity genetic that far and if the value of the coefficients similarity $>60 \%$ can be said to have a semblance of genetic were close. The according to Sukartini (2007), if an individual has a value of similarity that is small or relationship resemblance that far, then the people that have a variety of genes both for use activity breeding .

Differences in the appearance of the plant can be caused by the difference like the plant ( genetic ) or differences in the environment or to both mutual influences . To express its genetic in full, plants require state environmental optimum ( Sitompul and Guritno, 1995).

On the value of the coefficient of $33 \%$ ( Figure 1), accession is divided into two groups of primary, namely groups 1 and 2. Group 1 consisted of 42 accessions were divided into two subgroups, namely 1A consists of 40 ( RR1, RR2, RR4, RR15, RR3, RR7, RR8, RR13, RM1, RM3, RM5, RM7, RM4, RM13, RM15, RM15, RM18, RM16, RR5, RR6, RR9, RR12, RR12, RR14, RT1, RT3, RT8, RT2, RT7, RT11, RT11 RT9, RT12, RT13, RT17, RM 6, RM9, RM10, RM11, RM17, and RM19) accessions and 1B consisting of 2 ( RM20, RM21) accessions . In group 2 consisting of 12 accessions also divided into two subgroups namely 2A consisting of 10 (RR10, RR11, RM2, RM12, RM8，RT4，RT15，RT6，RT14，RT15) accessions and 2B consisting of 2 ( RT16, RT18) accession ( Table 3).

At the $100 \%$ coefficient value there are several grouping accessions, namely, RR1 with RR2, RR4, and RR15, R R3 with RR7, RR8, and RR13, RM1 with RM3, RM5, and RM17, RM4 with RM14, RM13 with RM15 and RM18, RR5 with RR6, RR9, and RR12, RT1, with RT3, RT8, and RT10, RT2 with RT7, RT9 with RT12 and RT13, RM6 with RM9, RM10, RM11, RM17, and RM19, 
RM20 with RM21, RM2 with RM12, RT4 with RT5 and RT6, RT14 with RT15, RT16 with RT18. Accession are flocking to the value of the coefficient of $100 \%$ indicates there is a similarity of character shapes stipules, the shape of leaves, forms the tip of the leaf, form the base of the leaf, the color of the leaves of young, the surface of the leaf, shape the edges of leaves, the color of ripe fruit, the shape of fruit, and form bean coffee robusta at three height . Clustering is intended for classifying objects based on the similarity of characteristics in between the objects the object of the . Objects are in classification to the one more clusters ( groups ) so that objects that are in the cluster will have a semblance of one with the other ( Santoso , 2014).

If the value of the coefficient of similarity approaching the numbers $1,0(100 \%)$, the diversity of genetic getting lower which means that individuals are similar but slightly or even not occur variations in genes. Whereas if the similarity coefficient approaches 0.1 (10\%), genetic diversity is high. Anas and Yoshida (2004) stated that the samples were located on a line that together tends to have a diversity of genetic were lower in samples such.

\section{FIGURES AND TABLES}

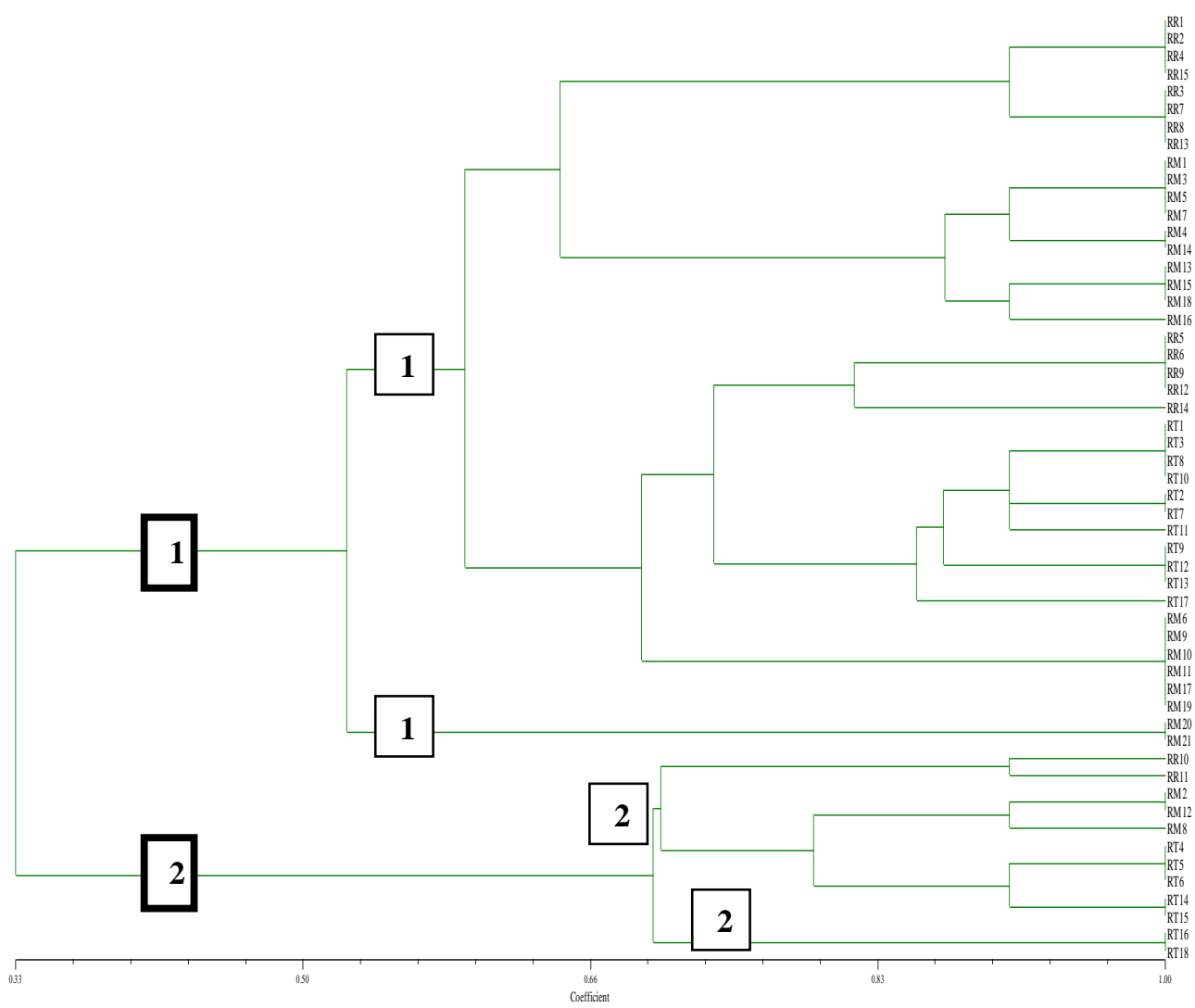

Fig.1: Dendogram 54 accessions of robusta coffee plants in three heights based on the character qualitative RR (Robusta plateau), RM (Robusta plateau Mediaum), RT (Robusta plateau)

Table.1: Grouping 54 Robusta Coffee Plants Accession at three altitudes in Merangin District Based on Qualitative Dendogram.

\begin{tabular}{ccl}
\hline $\begin{array}{c}\text { Main } \\
\text { Group }\end{array}$ & $\begin{array}{l}\text { Sub } \\
\text { Group }\end{array}$ & Accession \\
\hline 1 & 1A & RR1, RR2, RR4, RR15, RR3, RR7, RR8, RR13, RM1, RM3, RM5, RM7, RM4, RM14, RM13, \\
& & RM15, RM18, RM16, RR5, RR6, RR9, RR12, RR14, RT1, RT3, RT8, RT10, RT2, RT7, RT11, \\
& RT9, RT12, RT13, RT17, RM6, RM9, RM10, RM11, RM17, RM19 \\
& 1B & RM20, RM21 \\
& 2A & RR10, RR11, RM2, RM12, RM8, RT4, RT5, RT6, RT14, RT15 \\
& 2B & RT16, RT18 \\
\hline
\end{tabular}




\section{CONCLUSION}

The value of the coefficient of similarity is at $33 \%$ which indicates that the degree of similarity is small. Wet weight per 100 ripe fruits ripe, long bean coffee, as well as weight per 100 grains of coffee robusta scale on levels of water $12 \%$ shows an increasingly higher altitude of the place is getting better.

\section{REFERENCES}

[1] Badan Pusat Statistik. 2018. Jambi Dalam Angka. Provinsi Jambi.

[2] Balkaya, A., R. Yanmaz, and M. Ozbakır. 2009. Evaluation of variation in seed charactersin Turkish winter squash (Cucurbita maxima Duch.) populations. N. Z. J.Crop Hortic. Sci. 37(3): 167-178.

[3] Direktorat Jenderal Perkebunan Kemeterian Pertanian Republik Indonesia. 2018. Statistik Perkebunan Kopi Indonesia 2017 - 2019. Jakarta

[4] [GAEKI] Gabungan Eksportir Kopi Indonesia. 2014. Perkembangan dan Tantangan Produk Kopi Olahan Indonesia www.gaeki.or.id. [Diakses 31 Agustus 2019].

[5] [ICO] International Coffee Organization. 2019. Exports of all forms of coffee by exporting countries to all destinations 2019. http://www.ico.org. [Diakses 31 Agustus 2019]

[6] Najiyati S, Danarti. 2012. Kopi, Budidaya dan Penanganan Lepas Panen. Jakarta(ID): PT. Penebar Swadaya.

[7] Soeroso SSDA. 2012. Pala (Myristica spp.) Maluku Utara berdasarkan keragaman morfologi, kandungan atsiri, pendugaan seks tanaman dan analisis marka SSR [disertasi]. Bogor(ID): Institut Pertanian Bogor

[8] Sitompul S.M, B. Guritno, 1995. Analisis Pertumbuhan Tanaman Talas. Gadjah Mada University Press. Yogyakarta. Hal 68-78

[9] Sudarsono, Ratnawati \& Budiwati. (2005). Taksonomi Tumbuhan Tinggi. Universitas Negeri Malang. Malang.

[10] Sugiyono. 2007. Metode Penelitian Kuantitatif, Kualitatif dan R \& D. Bandung: Alfabeta.

[11] Sukartini. 2007. Pengelompokkan Aksesi Pisang Menggunakan Karakter Morfologi IPGRI. J Hortikultura17(1):26-33

[12] Sumarno dan Zuraida, N. 2008. Pengeloaan Plasma Nutfah Tanaman Terintegrasi dengan Pemuliaan Tanaman. Pusat Penelitian dan Pengembangan dan Pangan Bogor. Buletin Plasma Nutfah Vol. XIV (2)

[13] Susilo AW. 2008. Ketahanan tanaman kopi (Cofffea Spp.) terhadap hama penggerek buah kopi
(Hypothenemus hampei Ferr.). Review Penelitian Kopi dan Kakao. 24(1): 1-14.

[14] Stuessy, T.F. 1990. Plant taxonomy: The systematic evaluation of comparative data. Columbia University Press, New York: xvii + 514 hlm.

[15] Syukur M, S. Sujiprihati, dan R. Yunianti. 2012. Teknik Pemuliaan Tanaman. Penebar Swadaya. Jakarta.

[16] Tedianto. 2012. Karakteristik Labu Kuning (Cucurbita moschata) Berdasarkan Penanda Morfologi dan Kandungan Protein, Karbohidrat, Lemak pada Berbagai Ketinggian Tempat. (Tesis). Universitas Sebelas Maret. Surakarta.

[17] Van der Vossen, H.A.M., Soenaryo \& Mawardi, S. (2000). Coffea L. dalam : van der Vossen, H.A.M. \& Wessel, M. (Eds). Plant Resources of South-East Asia No.16: Stimulants. Backhuys Publisher, Leiden, The Netherlands. 6674.

[18] Van Steenis, C. G. G. J. Den Hoed. \& Eyma, P. J. (2008). Flora Untuk Sekolah di Indonesia. Pradnya Paramita, Jakarta. 